\title{
Seasonal Pattern of Prevalence and Excretion of Eggs of Baylisascaris transfuga in the Brown Bear (Ursus arctos)
}

\author{
Ladislav Molnár ${ }^{1}$, Alžbeta Königová ${ }^{2, *}{ }^{\mathbb{C}}$, Peter Major ${ }^{1}$, Zuzana Vasilková $^{2}{ }^{\mathbb{D}}$, \\ Martina Tomková ${ }^{3}$ and Marián Várady ${ }^{2}$ \\ 1 Clinic for Birds and Exotic Animals, University of Veterinary Medicine and Pharmacy, \\ 04001 Košice, Slovakia; ladislav.molnar@uvlf.sk (L.M.); major.dr@gmail.com (P.M.) \\ 2 Institute of Parasitology of the Slovak Academy of Sciences, 04001 Košice, Slovakia; vasilko@saske.sk (Z.V.); \\ varady@saske.sk (M.V.) \\ 3 Slovak Hydrometeorological Institute, Ďumbierska 26, 04117 Košice, Slovakia; martina.tomkova@shmu.sk \\ * Correspondence: konig@saske.sk; Tel.: +421-55-6334455
}

Received: 3 December 2020; Accepted: 15 December 2020; Published: 18 December 2020

check for updates

Simple Summary: The main goal of this study was to monitor the seasonal dynamics of faecal egg counts (FEC) expressed as eggs per gram (EPG) and intensity of excretion of the egg nematode Baylisascaris transfuga in the European brown bear over three years. The number of nematode eggs in the faecal samples began to rise in the spring and peaked in the autumn throughout the study period. Presence of nematode eggs in the samples was also observed in the winter season. Of the environmental factors, the seasonal dynamics and intensity of the infection were most influenced by temperature, while humidity and mean precipitation did not affect it. Increasing mean temperatures during the winter and short or no hibernation together with the presence of $B$. transfuga infection may negatively affect the health of infected bears. Due to the zoonotic potential of the parasite and the increased occurrence of bears in the vicinity of human dwellings, the dissemination of propagative stages may also pose a threat to human health.

\begin{abstract}
The seasonal dynamics of the prevalence, abundance, and mean intensity of egg excretion by the nematode parasite Baylisascaris transfuga in the European brown bear (Ursus arctos) were monitored relative to environmental factors (mean temperature, humidity, and temperature) over three years. The prevalence, abundance, and mean intensity of egg excretion tended to increase from spring to autumn throughout the monitoring period. The seasonal prevalence (84.2-90.6\%), abundance (470.2-545.3 eggs per gramme (EPG) of faeces), mean intensity of excretion (558.3-602.1 EPG), and number of eggs (1150 EPG) were highest in autumn. The prevalence of eggs (up to 48.5\%), abundance (37.8-60.6 EPG), and mean intensity of excretion (94.4-125.0 EPG) were high in winter, despite the period of hibernation. The seasonal dynamics of $B$. transfuga abundance in bears, the mean temperature between spring and autumn, and the seasonal trend of increase in intensity of egg excretion with temperature from winter to summer were interrelated. Abundance differed significantly between winter and autumn, spring and autumn, and summer and autumn $(p<0.0001)$ in all years and between spring and summer in $2016(p<0.005), 2017(p<0.05)$. B. transfuga abundance differed significantly between the seasons over the three years only in spring $(p \leq 0.0001)$.
\end{abstract}

Keywords: European brown bear; Baylisascaris transfuga; prevalence; seasonal dynamics 


\section{Introduction}

The European brown bear (Ursus arctos) is present in 22 European countries, with an estimated total number of approximately 17,000 individuals [1]. Most of these populations are strictly protected and are currently increasing [2]. The Carpathian population includes brown bears in Slovakia, Poland, the Ukraine, and Romania. The population in the Carpathian Mountains is estimated at about 8100 bears, and is the second largest in Europe. More than $90 \%$ of bears in Slovakia belong to the West Carpathian subpopulation, which is no longer isolated, but is again contiguous with that in the East Carpathian subpopulation in north-eastern Slovakia, south-eastern Poland, and the Ukrainian Carpathians. Some of these bears also likely have transborder home ranges [3]. Data from the State Nature Conservancy indicate that brown bears in Slovakia inhabit about 33\% of the area, covering $16,000 \mathrm{~km}^{2}[4,5]$. Štofik et al. [5] documented significant growth of the bear population over the last decades. Estimated population density was one bear per $<850$ ha in 2001 and one bear per $<380$ ha in 2014, i.e., a 2.2-fold increase in density. The estimated density in 2019 was one bear per $<310$ ha [4]. The estimated population in 2014 based on faecal genetic analyses was 1256 individuals, and the current number of brown bears in Slovakia is about 1500-1600 individuals [6,7]. This bear population growth can be explained by the reduction of human settlements and increasing forestation and food sours [8], and by the protection of the brown bear. According to the Habitats Directive (Annex IV of 92/43/EEC Directive), the Slovak Act on Nature and Landscape Protection (No. 543/2002) and the Decree of the Ministry of Environment (No. 24/2003), the brown bear is a species of European importance with a high protection priority. Conservation and management are guided by the accepted management plan for large carnivores in Slovakia. The bear population has been increasing from the long-term perspective [5]. Since bears utilize food sources provided by a man for wild boar, we presume that the population growth of brown bears in region [5] can also be stimulated by supplementary feeding by hunters. This leads to sufficient food source for non-denning bears and subsequently decreased winter home range.

The changing living conditions of wild bears, their shrinking home ranges, the impact of urbanization (human density, or human agricultural land use, developed and forested) are factors supporting the transmission of infective stages of nematodes, which have the potential to cause parasitic zoonoses in humans [9]. All species of Baylisascaris nematodes in wild carnivores can be regarded as potentially zoonotic [10]. Kazacos [11] stated that all Baylisascaris species could be considered potential etiological agents of larva migrans depending on the dose of infective eggs, although $B$. procyonis and B. columnaris in common raccoons are the primary causative agents of zoonoses associated with wild carnivores. B. transfuga is a widespread pathogen in populations of free-ranging bears in many areas of the world [12,13]. Adult B. transfuga are first detected in bear cubs from five months of age [14], and infection decreases with age. Partridge [15] and Moran et al. [16] reported that young and immature bears were more susceptible. The pathogenicity of intestinal infection with B. transfuga is low in bears; one case of granulomatous peritonitis caused by nematodes was described in a cub [17]. Little information is available about the life cycle of $B$. transfuga in wild bears. The complete life cycles of most species of Baylisascaris are unknown [18]. Moran et al. [16] stated that infection with B. transfuga could be direct or via a paratenic host, such as wild rodents. Encapsulated larvae of B. transfuga have been detected in the mesentery and the wall of the large intestine of the grey-sided vole (Myodes rufocanus) and the tundra vole (M. oeconomus) [19]. Abdelrasoul and Fowler [20] found that the life cycle was direct, but could also be indirect via encysted larvae using various rodents, birds, or insects as intermediate hosts. Transmammary and transplacental transmission are apparently unlikely [11]. In contrast, larvae migrate through various tissues in rodents, e.g., white mice and Mongolian gerbils, which are susceptible to experimental infection with B. transfuga, growing and developing to the third stage and causing various degrees of visceral, neural, or ocular larva migrans [21]. Larva migrans are the most serious complication associated with Baylisascaris, mainly caused by larvae of the common raccoon parasite B. procyonis in intermediate and occasional hosts. Baylisascaris procyonis is the most common clinical larva migrans in animals, in which it is usually associated with fatal or severe 
neurological disease. It is known for aggressive somatic migration, larval invasion of the central nervous system, and the capability for continued larval growth within intermediate hosts [22]. A single larva in the brain of a rodent is enough to cause clinical signs, even death $[11,23]$. In infants and young children, in its most severe form, B. procyonis is a rare cause of fatal or neurologically devastating neural larva migrans [22].

Definitive hosts of $B$. transfuga rarely show clinical signs unless heavy infections of adult worms block the digestive tract. Wallach and Boever [24] reported symptoms of diarrhoea, anorexia, and dry and severe cough, with the occasional presence of parasites in the faeces. Heavy infestation can lead to intestinal obstruction and subsequently to death [24,25]. Foster et al. [14] reported that black bear cubs harboured 1-39 nematodes in their intestines. Infected captive bears may shed as many as 10,000-20,000 eggs per gramme (EPG) of faeces [26] and thereby heavily contaminate their domestic areas.

Most information about the prevalence of B. transfuga in populations of wild bears has been from the American, Canadian, and Russian populations of black, brown, grizzly, and polar bears, respectively [14,27-33]. Information about the prevalence of $B$. transfuga in populations of wild brown bears in Europe is limited [1,34-39], and little is known about the seasonal dynamics of B. transfuga in these populations $[36-38,40]$. The seasonal dynamics of $B$. transfuga in wild carnivores can also be influenced by external factors such as temperature, humidity, and rainfall. Sufficient humidity and optimal temperature support the growth and survival of infective stages of nematodes, leading to higher contamination of carnivore environments. Climatic factors can impact the growth and survival of infective stages of Baylisascaris nematode. Temperature, humidity, and rainfall can affect environmental moisture retention of soils that were associated with transmission to paratenic hosts by improving viability at or near the surface [9]. Moisture and particle size also can affect egg viability, keeping viable eggs and can increase the potential risk of infection [41].

The present study determined the seasonal changes during a three-year period in the prevalence of B. transfuga eggs in faecal samples of the brown bear in Poloniny National Park, Eastern Carpathians, in Slovakia.

\section{Materials and Methods}

Permission for conducting a study was granted by the Administration of the Poloniny National Park. According to national law, formal ethical approval is not required for studies based on the monitoring of indirect signs of animals, such as collection of faecal samples.

\subsection{Study Area}

The study was conducted at the East Carpathians Biosphere Reserve (ECBR, UNESCO Man and Biosphere), the first European trilateral Man and Biosphere reserve (Slovakia/Poland/Ukraine) and the second largest biosphere reserve in Europe. The reserve covers an area of 208,089 ha (the Polish, Slovak, and Ukrainian parts occupy $52.2 \%, 19.59 \%$, and $28.16 \%$, respectively) includes six large protected areas, and contains the largest European complexes of original beech forests, and East Carpathian montane meadows. Poloniny National Park, part of ECBR, is the largest forest complex in Slovakia, with an area of 29,805 ha (a buffer zone of 10,973 ha). Endemic communities are predominant, with a large local population of European brown bears. The estimated density varies between 5 and 11 bears per $100 \mathrm{~km}^{2}$.

\subsection{Parasitological Examinations}

A total of 524 faecal samples from brown bears were collected at the Poloniny National Park in north-eastern Slovakia from January 2016 to December 2018. The samples were collected with the assistance of the staff of the national park from several bear territories with presumed or reported occurrences of the animals (Figure 1). The national management plan for large carnivores estimates that the population size consists of around 35 bear individuals in the present time (2016-2018). Collection of 
bear faeces was roughly in the same point of an area usually correlated with hunters' feeding places, salt lick sites, or snow tracking in the winter period. During the snow season, bear tracks were followed in opposite direction of the bear movement to avoid disturbing the animal. Length and width of the footprint was recorded, if possible, on the snow or mud to identify individual bears. In the periods without snow cover, the faeces were collected systematically during the whole period following the method of Persson [42] et al. (2001) from the areas with reported and suspected occurrence of bears (orchards, roads, feeding racks). A GPS device (Garmin eTrex Vista H) was used to store the position and altitude of exact localities to avoid multiple sampling from the same scats. The numbers of faecal sampled was determined monthly.

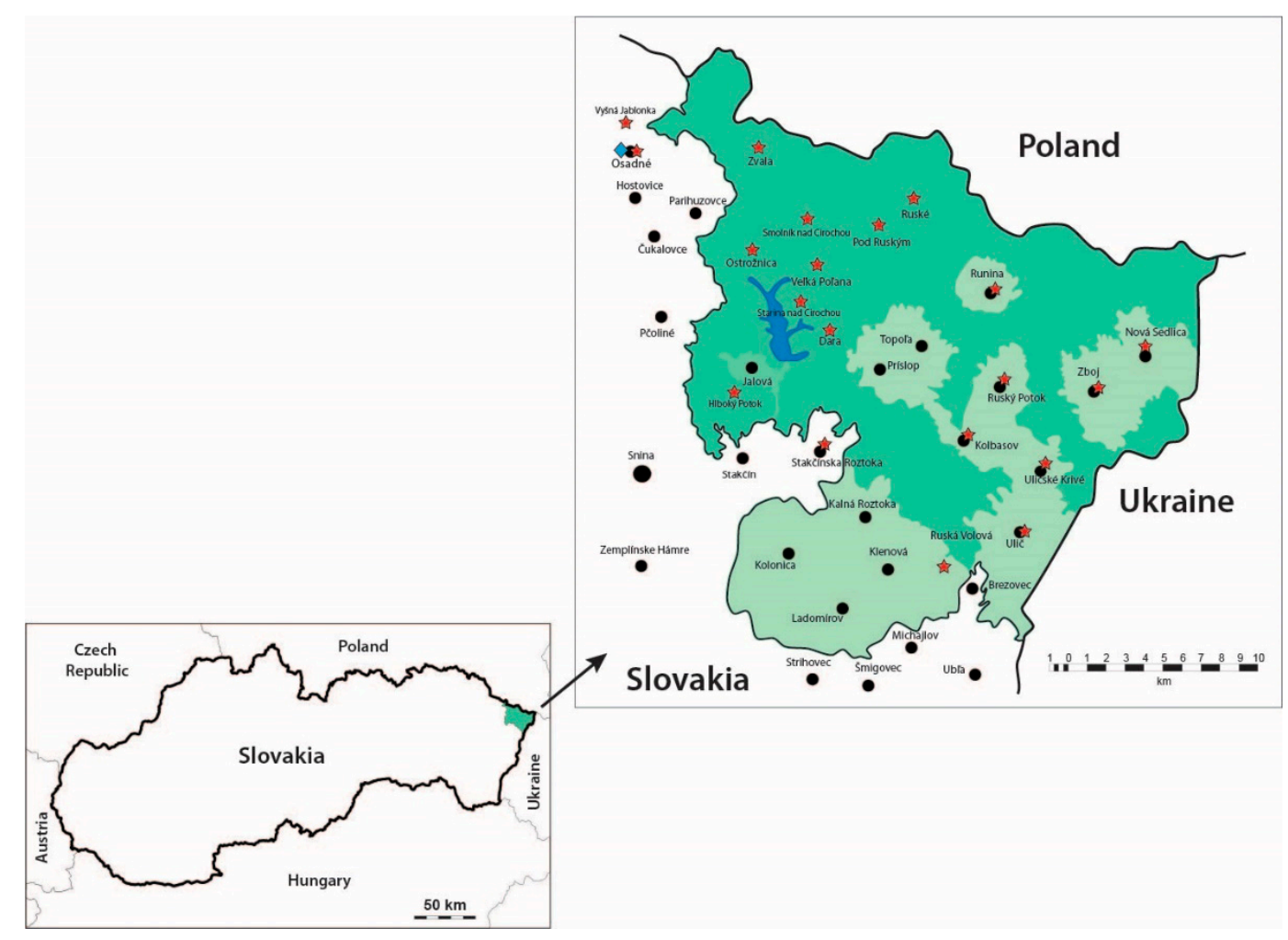

Figure 1. Distribution of the brown bear faecal samples in the study area in Poloniny National Park, Slovakia ( $\star$-sampling sites; $\diamond$-Hydrometeorological station, National Park Poloniny in Osadné).

Each faecal sample was stored in a plastic container at $4{ }^{\circ} \mathrm{C}$ and subsequently frozen until further processing. Frozen samples were thawed $24 \mathrm{~h}$ prior to coprological examination. All samples were analysed no later than two weeks after collection. The faecal egg count (FEC) was used to monitor the prevalence of the nematode $B$. transfuga in brown bears. Baylisascaris FEC were performed using the coprological McMaster technique according Coles et al. [43] with Sheather's sugar flotation solution (1.25 specific gravity) and expressed as EPG (eggs per gram). Identification of Baylisascaris transfuga eggs was performed based on the morphology of the eggs by Sprent [44], and Kazacos and Turek [45]. The data on $B$. transfuga eggs were used to estimate prevalence, based the recommendations of Margolis et al. [46]: Prevalence (\%), number of bears infected with B. transfuga eggs excreted in faecal samples divided by total number of bears examined. Mean excretion of eggs (EPG), total number of excreting of $B$. transfuga eggs in a bear faecal sample divided by number of infected bears; and abundance (EPG), total number of excreting of $B$. transfuga eggs in a bear faecal sample divided by total number of bears examined.

Basic climatological data, mean air temperature, minimum and maximum air temperatures, mean rainfall, and mean relative air humidity for 2016-2018 were obtained from the Slovak Hydrometeorological Institute (SHI), from the particular Hydrometeorological station, National Park 
Poloniny in Osadné (Figure 1). The data were analysed for the four seasons to assess the influence of meteorological factors: Spring (March-May), summer (June-August), autumn (September-November), and winter (December-February). The Kruskal-Wallis test (nonparametric ANOVA) was used to identify significant differences between seasonal prevalences (spring, summer, autumn, and winter) at $p<0.05$ (GraphPad Software, San Diego, CA, USA).

\section{Results}

\subsection{Seasonal Prevalence of B. transfuga in the European Brown Bear}

The seasonal dynamics of the prevalence of B. transfuga eggs in brown bears (a total of 524 faecal samples) in connection to temperature for three years is shown in Figure 2. The prevalence of baylisascariasis steadily increased over the years from spring to autumn. The difference of prevalence in spring is not statistically significant between 2016 (10.3\%) and 2017 (19.1\%), but significantly higher prevalence was observed in 2018 (59.5\%). Prevalence in summer was similar (59.6-63.6\%). Prevalence was highest in autumn (from 84.2 to 90.6\%). Prevalence in winter was high (38.1-48.5\%) in non-denning bears. Similar patterns of variation were observed between the dynamics and variations in mean temperature was noted in spring and autumn (temperature was recorded in the same range and no interannual differences among temperature a same season were determined) (Figure 2).

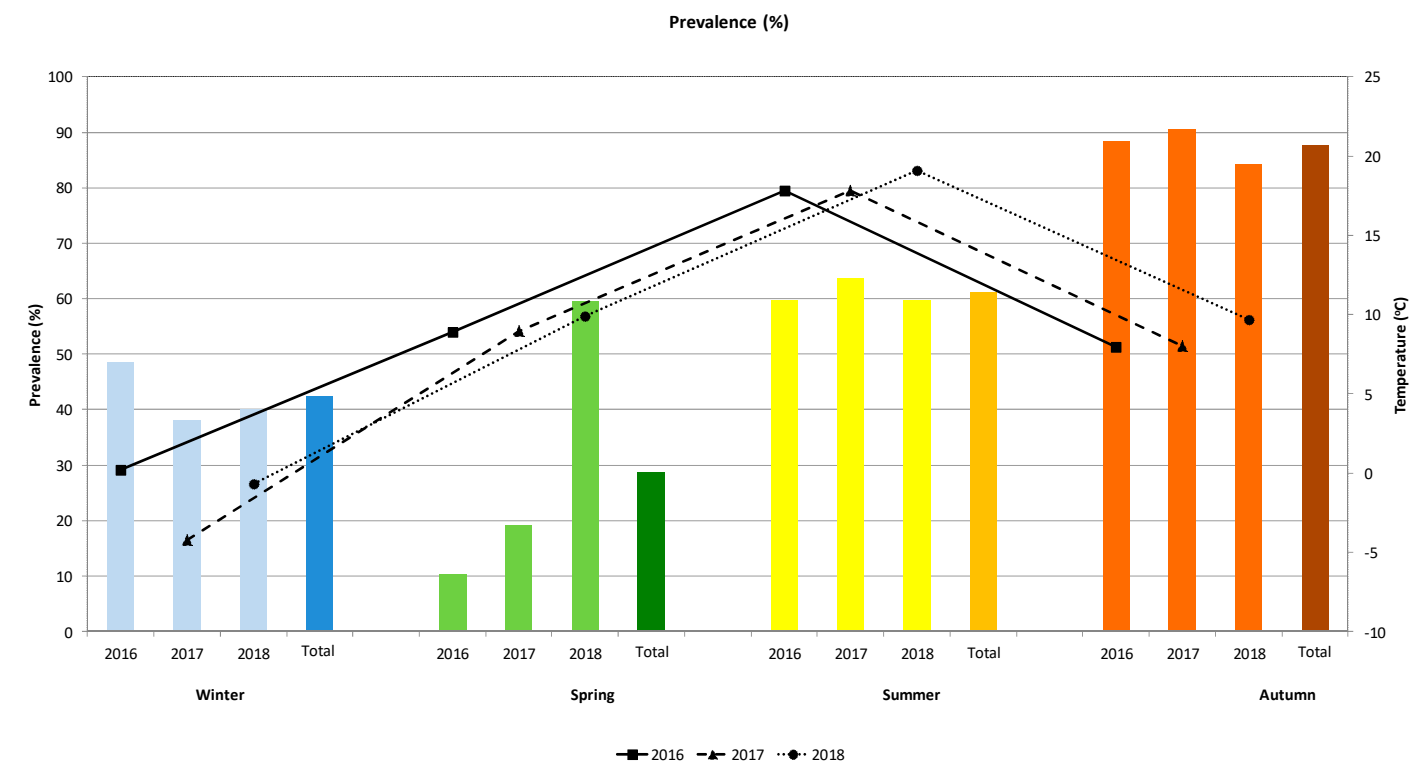

Figure 2. Prevalence of eggs of the nematode B. transfuga in the faecal samples of the brown bear (Ursus arctos) and mean temperature $\left({ }^{\circ} \mathrm{C}\right.$ ) during different seasons of the three-year survey.

\subsection{Seasonal Abundance of B. transfuga in the European Brown Bear}

Figure 3 shows the seasonal dynamics of the abundance of baylisascariasis in bear faecal samples and the variations in mean temperature during the three-year period, with an increasing trend from spring to autumn. Abundance was lowest in spring (11.5 \pm 43.6 EPG \pm SD), with a maximum EPG of 250 (Table 1). Abundance in summer varied from 110.0 \pm 135.9 to $149.0 \pm 178.6$ EPG during the study period. Although abundance was higher in winter $(37.8 \pm 70.0$ to $60.6 \pm 93.3 \mathrm{EPG})$ than in spring, abundance was not so high in the other season. The similar patterns of variation between the abundance of $B$. transfuga and variations in mean temperature were recorded from winter to summer. The abundance of baylisascariasis increased with temperature from winter to summer for the three years, except in spring 2016 and 2017, when EPGs were lower (11.5 \pm 43.6 and 22.6 \pm 57.6). Abundance increased rapidly in autumn (470.2 \pm 268.9 to $545.3 \pm 304.2$ EPG) (Figure 3), similar to the autumn prevalence rates (84.2-90.6\%) (Figure 2). 


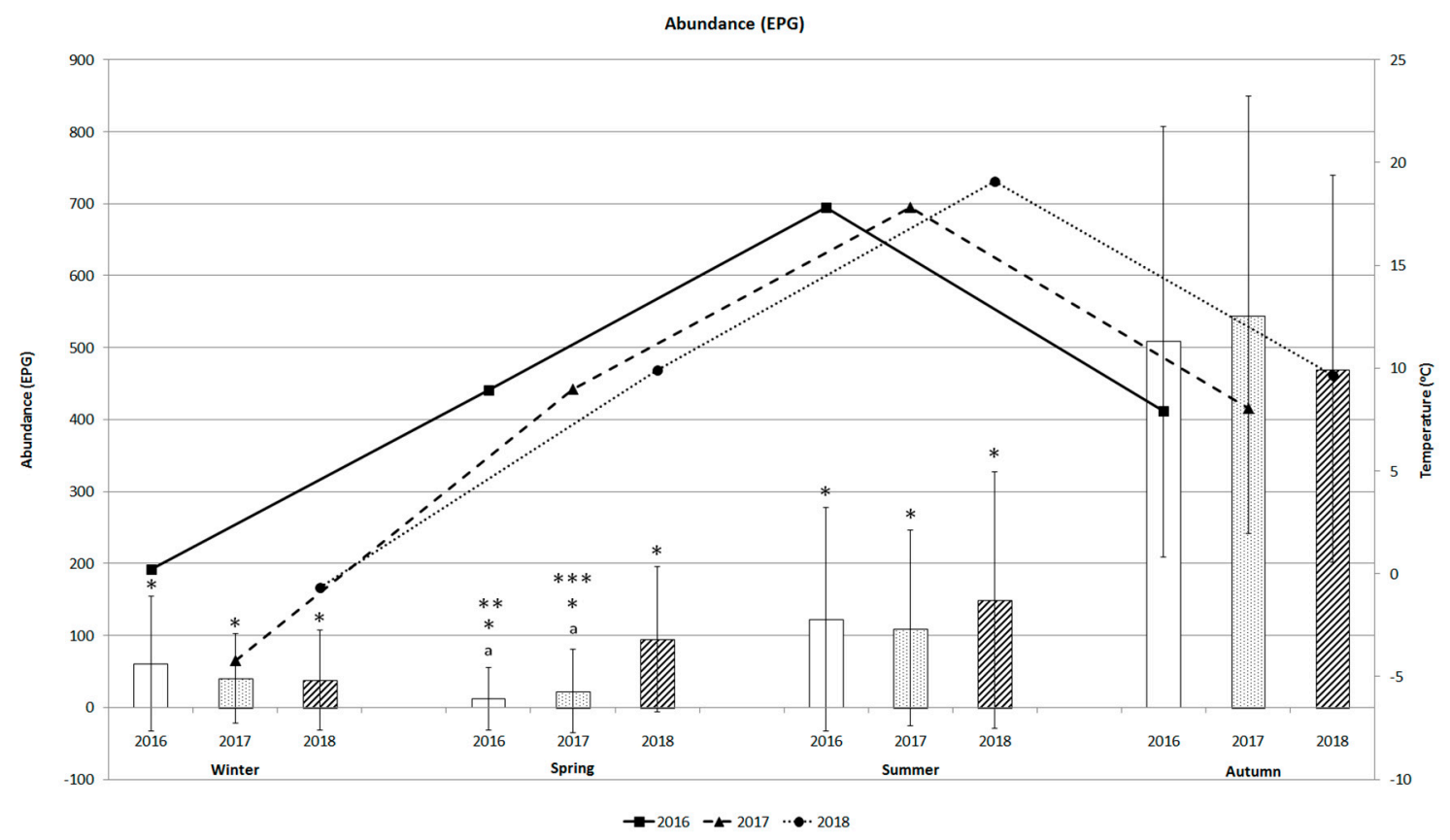

Figure 3. Abundance (mean EPG) of B. transfuga eggs in the faecal samples of the brown bear (Ursus arctos) and mean temperature $\left({ }^{\circ} \mathrm{C}\right.$ ) during different seasons of the three-year survey; a significant difference between spring 2016 and 2017, and spring 2018, $p<0.0001{ }^{*}{ }^{*}$, significant differences between autumn and winter, spring, and summer 2016, 2017, and 2018; $p<0.0001 ;{ }^{* *}$, significant difference between spring and summer 2016, $p<0.005 ;{ }^{* * *}$, significant difference between spring and summer $2017, p<0.05$.

Seasonal B. transfuga eggs' abundance in brown bears differed significantly only between spring 2016 and $2018(p<0.0001)$, and spring 2017 and $2018(p=0.0001)$. B. transfuga eggs' abundance in brown bears differed significantly between winter and autumn $(p<0.0001)$, spring and autumn $(p<0.0001)$, summer and autumn $(p<0.0001)$, and spring and summer 2016-2017 $(p<0.005 ; p<0.05)$ (Figure 3$)$.

\subsection{Seasonal Mean Excretion of B. transfuga Eggs in the European Brown Bear}

The seasonal dynamics of mean excretion of B. transfuga eggs in the faecal samples from brown bears and the variations in mean temperature during the three years are shown in Figure 4. Mean excretion of B. transfuga eggs in bears seasonally increased from winter to autumn in all three years. The excretion of eggs in 2016 differed significantly between winter and autumn $(p<0.0001)$, spring and autumn $(p<0.005)$, and summer and autumn $(p<0.0001)$. The excretion of eggs in 2017 differed significantly between winter and autumn, spring and autumn, and summer and autumn ( $p<0.0001$ in all cases). Mean excretion did not differ significantly between the seasons over the three years. The intensity of excretion in 2018 differed significantly between winter and summer and winter and autumn $(p<0.005$ in both cases). Mean excretion was lowest in winter ( $94.4 \pm 83.8$ to $125.0 \pm 100.0 \mathrm{EPG} \pm \mathrm{SD}$ ), with a maximum of 400 EPG (winter 2018). Mean excretion was low in spring 2016 (112.5 \pm 94.7 EPG), with a maximum of 250 EPG. Mean excretion increased in summer, with EPGs varying between $172.9 \pm 134.7$ and $205.4 \pm 152.4$ EPG, with a maximum of 550 EPG. Mean excretion was highest in autumn (from $558.3 \pm 189.4$ to $602.1 \pm 259.7$ EPG), with a maximum of 1550 EPG (2017). 
Table 1. Number of examined and infected faecal samples, minimum and maximum eggs per gram (EPG) of faeces, abundance, mean intensity of excretion, and prevalence of B. transfuga eggs in the brown bear (Ursus arctos) during different seasons of the three-year survey.

\begin{tabular}{|c|c|c|c|c|c|c|c|c|}
\hline Season & Year & $\begin{array}{c}\text { Number } \\
\text { of Examined }\end{array}$ & $\begin{array}{l}\text { Number } \\
\text { of Infected }\end{array}$ & Minimum EPG & Maximum EPG & $\begin{array}{l}\text { Abundance } \\
(\mathrm{EPG} \pm \mathrm{SD})\end{array}$ & $\begin{array}{c}\text { Mean Intensity } \\
\text { of Excretion }(E P G \pm S D)\end{array}$ & $\begin{array}{l}\text { Prevalence (\%) } \\
\text { 95\% CI }\end{array}$ \\
\hline \multirow{3}{*}{ Winter } & 2016 & 33 & 16 & 0 & 350 & $60.6 \pm 93.3$ & $125.0 \pm 100.0$ & $48.5(0.308-0.664)$ \\
\hline & 2017 & 21 & 8 & 0 & 200 & $40.5 \pm 62.5$ & $106.3 \pm 56.3$ & $38.1(0.181-0.616)$ \\
\hline & 2018 & 45 & 18 & 0 & 400 & $37.8 \pm 70.0$ & $94.4 \pm 83.8$ & $40.0(0.257-0.557)$ \\
\hline \multirow{3}{*}{ Spring } & 2016 & 39 & 4 & 0 & 250 & $11.5 \pm 43.6$ & $112.5 \pm 94.7$ & $10.3(0.029-0.242)$ \\
\hline & 2017 & 42 & 8 & 0 & 250 & $22.6 \pm 57.6$ & $118.8 \pm 79.9$ & $19.0(0.086-0.341)$ \\
\hline & 2018 & 37 & 22 & 0 & 350 & $94.6 \pm 101.2$ & $159.1 \pm 82.6$ & $59.5(0.421-0.753)$ \\
\hline \multirow{3}{*}{ Summer } & 2016 & 47 & 28 & 0 & 500 & $122.3 \pm 154.9$ & $205.4 \pm 152.4$ & $59.6(0.443-0.736)$ \\
\hline & 2017 & 55 & 35 & 0 & 500 & $110.0 \pm 135.9$ & $172.9 \pm 134.7$ & $63.6(0.496-0.762)$ \\
\hline & 2018 & 52 & 31 & 0 & 550 & $149.0 \pm 178.6$ & $250 \pm 167.8$ & $59.6(0.451-0.73)$ \\
\hline \multirow{3}{*}{ Autumn } & 2016 & 43 & 38 & 0 & 1300 & $508.1 \pm 299$ & $575.0 \pm 249.0$ & $88.4(0.749-0.961)$ \\
\hline & 2017 & 53 & 48 & 0 & 1550 & $545.3 \pm 304.2$ & $602.1 \pm 259.7$ & $90.6(0.793-0.968)$ \\
\hline & 2018 & 57 & 48 & 0 & 950 & $470.2 \pm 268.9$ & $558.3 \pm 189.4$ & $84.2(0.721-0.925)$ \\
\hline
\end{tabular}




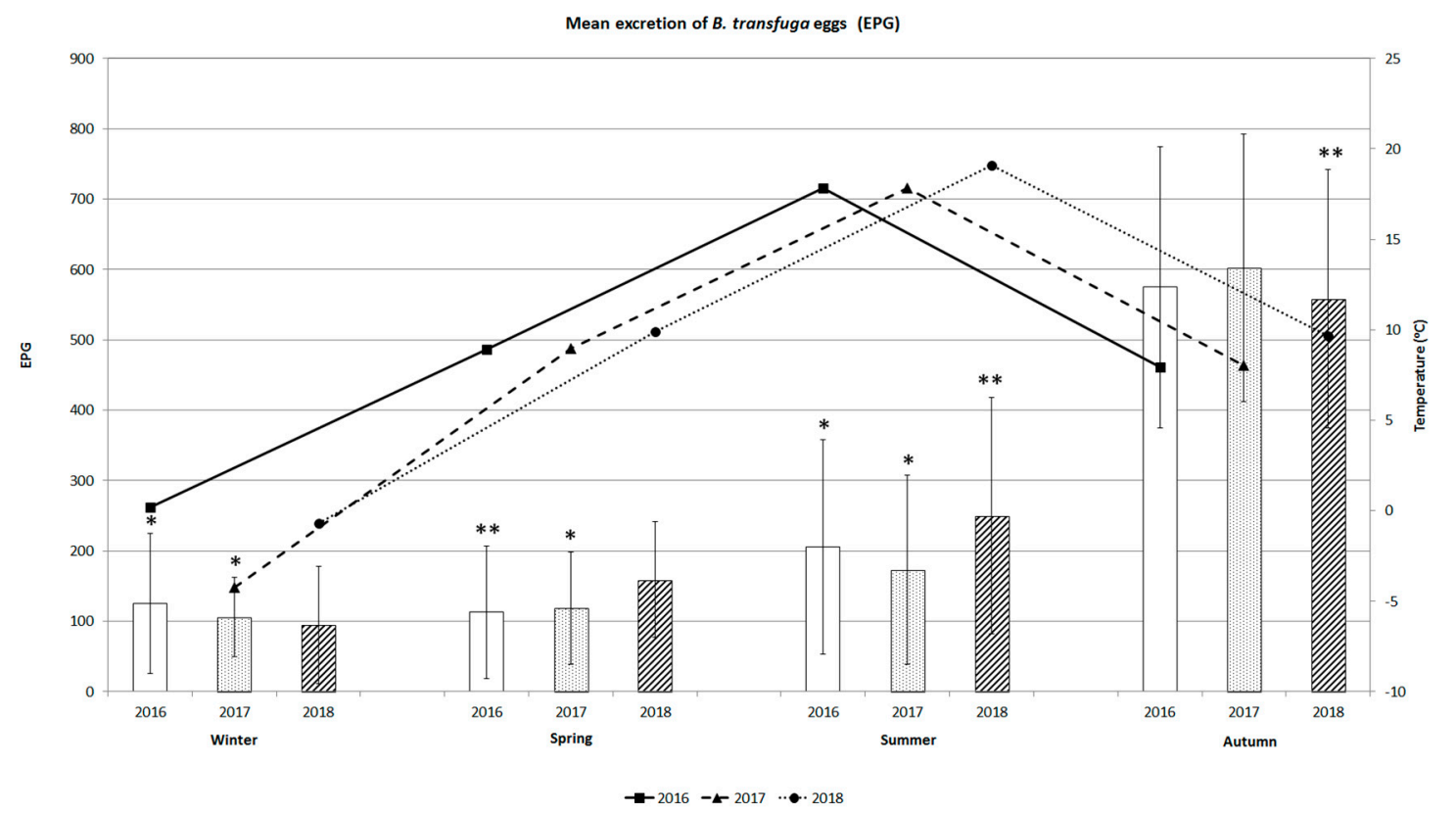

Figure 4. Mean excretion of B. transfuga eggs (EPG) in the brown bear (Ursus arctos) and mean temperature $\left({ }^{\circ} \mathrm{C}\right)$ during different seasons of the three-year survey; ${ }^{*}$, significant differences between autumn, winter, and summer 2016 and between winter, spring, and summer 2017; $p<0.0001$; **, significant differences between spring and autumn 2016 and between winter, summer, and autumn $2018, p<0.00$.

The excretion of parasitic eggs was highest in autumn, with the maximum EPG over the three years. Mean excretion tended to increase with temperature from winter to summer.

Any relationship was not observed between data on precipitation and humidity and seasonal results of FEC. In our study, we also investigated the relationship between the occurrence of $B$. transfuga and mean precipitation and humidity (Table 2). We did not observe any relationship between our findings and any of the mentioned climatic parameters.

Table 2. Basic climatological parameters, mean temperature, minimum and maximum temperatures, mean rainfall, and mean humidity, during the three-year survey (2016-2018).

\begin{tabular}{|c|c|c|c|c|c|c|c|c|c|c|c|c|c|c|c|}
\hline \multirow[t]{3}{*}{ Season } & \multicolumn{9}{|c|}{ Temperature $\left({ }^{\circ} \mathrm{C}\right)$} & \multicolumn{3}{|c|}{ Mean Rainfall (mm) } & \multicolumn{3}{|c|}{ Mean Humidity (\%) } \\
\hline & \multicolumn{3}{|c|}{2016} & \multicolumn{3}{|c|}{2017} & \multicolumn{3}{|c|}{2018} & \multirow{2}{*}{2016} & \multirow{2}{*}{2017} & \multirow{2}{*}{2018} & \multirow{2}{*}{2016} & \multirow{2}{*}{2017} & \multirow{2}{*}{2018} \\
\hline & Mean & Min & Max & Mean & Min & Max & Mean & Min & Max & & & & & & \\
\hline Winter & 0.2 & -16.6 & 14.5 & -4.2 & -20.5 & 12.5 & -0.7 & -14.2 & 10.5 & 90.8 & 56.3 & 66.8 & 83.1 & 85.5 & 83.2 \\
\hline Spring & 8.9 & -6.2 & 26.9 & 9.0 & -3.4 & 26.3 & 9.9 & -18.0 & 27.6 & 53.9 & 62.1 & 70.9 & 76.9 & 74.2 & 73.7 \\
\hline Summer & 17.8 & 3.1 & 32.2 & 17.8 & 4.2 & 32.0 & 19.1 & 4.7 & 30.7 & 118.4 & 88.1 & 105.6 & 72.9 & 75.6 & 77.8 \\
\hline Autumn & 7.9 & -8.9 & 28.0 & 8.0 & -7.2 & 28.5 & 9.7 & -13.0 & 28.6 & 87.7 & 99.8 & 40.3 & 82.8 & 85.5 & 79.7 \\
\hline
\end{tabular}

Source: SHI, Bratislava, Hydrometeorological station Osadné, SR.

\section{Discussion}

Our study describes seasonal patterns of mean excretion, abundance, and prevalence of B. transfuga eggs by brown bears in a Central Europe area. The prevalence, intensity, and geographic distribution of $B$. transfuga infections have been confirmed worldwide in free-ranging bears such as the American black bear and grizzly bear, the European brown bear, and the polar bear. The seasonal dynamics of $B$. transfuga infections in populations of wild bears could also be influenced by the large differences between bear species and the genetic variability and adaptability of nematodes to a wide range of external temperature differences. Further studies would be useful to clarify the intra- and interspecific 
relationships amongst $B$. transfuga from different geographic areas and bear species and to address epidemiological and zoonotic patterns of this bear nematode.

Only limited data has been reported for the seasonal dynamics of B. transfuga prevalence in populations of free-ranging bears, with some conflicting results. The prevalence of B. transfuga in American and Canadian populations of wild bears has been reported in several studies $[14,25,28-30,32,47-50]$, but only a few studies have attempted to investigate seasonal trends in prevalence. One of the studies comparing the incidence of eggs confirmed a higher prevalence in spring $(42 \%)$ compared to autumn prior to denning (13\%) in black bears in Canada [29]. Such an opposite trend to our findings may have been due to the development of larvae surviving hibernation [29]. Several studies have provided evidence that intestinal parasites that feed directly on the host organism pass from the gastrointestinal tract before the onset of hibernation [28,49]. Choquette et al. [49] and Rausch [47] also hypothesised that nematodes were eliminated prior to hibernation in bears. Rogers [28] found that bears excreted B. transfuga eggs in the spring soon after hibernation and found evidence of egg excretion immediately prior to denning, so whether or not parasitic infections are cleared during winter hibernation remains unclear, and the apparent elimination of $B$. transfuga during hibernation is poorly understood. Rogers [28], however, confirmed that baylisascariasis in a population of wild bears occurred mainly in summer (75\%). Similarly, Manville [50] reported the highest prevalence of B. transfuga eggs (64\%) and adult parasites (89\%) of American black bears (Ursus americanus) in summer based on faecal floatation and necropsy. Additionally, Clark et al. [48] found that the incidence of B. transfuga infection peaked from June to August and was lower during autumn and winter. Gau et al. [30] and Catalano et al. [32], however, observed the opposite seasonal trend, with peaks in autumn in black bears and grizzly bears in Canada, consistent with our results. Gau et al. [30] reported that the prevalence of gastrointestinal parasites, including Baylisascaris, in grizzly bear faeces was low in spring $(31 \%)$ and high in autumn $(58 \%)$ based on faecal floatation. Such dynamics may have been due to the expulsion of adult nematodes before hibernation and subsequent reinfection in spring, because bears restrict their food intake and evacuate their bowels shortly before hibernation. Catalano et al. [32] observed the seasonal trend in prevalence based on the collection of nematodes at necropsy, with peaks in autumn (87.5\%) in grizzly and black bears.

Little information is available on the prevalence of $B$. transfuga in populations of wild brown bears in Europe [1,35-40]. Only a few of these studies have attempted to evaluate the seasonal dynamics of this nematode. De Ambrogi et al. [39] described B. transfuga prevalence (13.5\%) in free-ranging European brown bears in Croatia based on a coprological study. Goldova et al. [36] identified gastrointestinal parasites in faecal samples in Slovakia, with a predominant prevalence of $B$. transfuga (72.34\%). The prevalence of baylisascariasis defined by FEC coprological method in brown bears during the three years of our study was highest in autumn. The FEC coprological non-invasive method is routinely used for detecting Baylisascaris in raccoon faeces and in the environment $[51,52]$. Limitation of this coprological non-invasive method could be false-negative stool examination results [51,52]. Despite the large number of eggs that are eliminated, it is recommended that three daily faecal samples be examined for Baylisascaris in raccoons [51], but it was not possible in wild bears. The highest prevalence in autumn in our study may be highly influenced by interactions such as age and sex of the examined bears. The intensity of egg excretion at one sampling site may be influenced by the fact that the source of the samples may be individuals of different ages. Among other factors, the age composition of the studied bears may have had a significant effect on the high prevalence of $B$. transfuga in our results. As is well known, juvenile raccoons are susceptible to infection through ingestion of eggs, while the older bears become infected through paratenic hosts [11], and immunity to larvae is developed following primary exposure in young animals, which decreases the burdens of parasites in future infections [51]. Young racoons can produce an egg output of 115,000-179,000 eggs per day [53]. Differences in prevalence between the sexes were also confirmed in raccoons, where higher prevalence was recorded in males than in females. Transplacental and transmammary transmission has been described in raccoon females $[11,54]$. Previous ingestion of larvated eggs is probably cumulative and 
may be affected by factors such as prepatent period (a prepatent period of 7-10 weeks), and also bear physiology changes as hyperphagia before hibernation.

The seasonal dynamics of $B$. transfuga prevalence in bears could be more influenced by internal factors such as hormonal and metabolic changes occurring before, during, and after bear hibernation. The occurrence of roundworms in hibernating bears in spring could be related to brown fat and the hypothalamic hormone, which affect the bear's carbohydrate metabolism by up to $75 \%$. Bear hibernation could affect the metabolism of intestinal nematodes. Glycogen is apparently synthesized from hexoses and plays an important role in supplying energy to nematodes [37]. Hibernation in relation to parasite metabolism has been described by several authors [28,49]. Finnegan [37] hypothesised that adult parasites usually died during hibernation in winter due to carbohydrate deficiency and subsequently disintegrated. Bears accumulate large stores of body fat during late summer and autumn necessary for winter hibernation. They have a hyperphagic phase in which food intake increases 2-3-fold, and their body weight can increase by 30-35\% [55]. Hyperphagia provides a sufficient source of carbohydrates for the survival and reproduction of nematodes [37]. Adult nematodes accumulate in the intestinal tracts of bears beginning in spring, which could be correlated with the highest seasonal peak in the prevalence of B. transfuga in bears in autumn. However, the mechanism of hibernation in bears is not well known, but is likely to be influenced by the interaction of several stimuli, including reduced food availability, low temperature, snowfall, daylight, physical conditions, sex, age, and reproductive status, and may also be influenced by bear species [56].

The high seasonal prevalence of B. transfuga in non-denning bears in winter is a concern and may be a consequence of the increase in mean temperatures due to global warming or to supplemental food sources provided by hunters in winter. Insufficient hibernation time due to warm winters and the consequent high prevalence of Baylisascaris infection can negatively affect the health of infected bears. The bear's carbohydrate metabolism in non-denning bears in winter is still built up. Is it assumed that bear hibernation could be negatively affected by the metabolism of intestinal nematodes and lead to "clearing up". This hypothesis can mainly affect juvenile subadults in bears which did not build up sufficient fat deposits and contribute to worsening body condition in spring time. Hibernation in relation to parasite metabolism has been described by several authors [28,49]. Bears, however, may not hibernate in mild winters [57]. The immobilisation of bears could be associated with mild winter temperatures due to global warming. The availability of sufficient food sources until late autumn and winter is another important factor associated with the delay or elimination of bear hibernation. Additionally, intensive feeding of wild bears with maize, as a source of carbohydrates, led to the activity of bears during winter [58,59].

The prevalence of baylisascariasis in brown bears during the three years of our study was highest in autumn. Our findings are consistent with most studies that have investigated the seasonal dynamics of $B$. transfuga in bears $[38,40]$. These studies found that the prevalence was highest in autumn or winter and lowest in spring. Orosová et al. [40], however, found that the prevalence of Baylisascaris was highest in autumn (85.71\%) and early winter (100\%). Similar results were reported by Major et al. [38] in their coprological study, who also observed that the prevalence of $B$. transfuga was highest in autumn and winter and lowest in spring, which corresponds to the results of our study. Several studies have confirmed the occurrence of parasites in bears during the winter, when bears should hibernate $[36,38,40]$.

We also observed a seasonal occurrence of nematode eggs in bear faeces during the winter. Our study recorded the prevalence of B. transfuga excreted eggs in faecal samples in the bears up to $48.5 \%$. Štrkolcová et al. [34] suggested that the high prevalence of endoparasites in winter was associated with relatively warm winters, which shortened or eliminated hibernation. However, it has been reported that seasonal pattern of B. procyonis in racoons may be disturbed in warmer southern regions of the United States [60,61]. So, the goal of our study was to confirm or refute this temporal seasonal pattern in the conditions of mild climate in Central Europe. The increase in temperatures during the winter has been observed in the mild climatic conditions of Central Europe in recent years. 
For this reason, we decided to monitor the prevalence of $B$. transfuga and the nematode egg excretion in brown bears' faecal samples during all seasons at monthly intervals over 3 years. To a lesser extent, soil type, habitat fragmentation, and other environmental components, such as road density, have been assessed as risk factors for parasitic infection [9]. Increased risk of transmitting Baylisascaris infection to paratenic hosts may affect the factors such as moisture retention and size of particles of the soil. Moisture and particle size also can affect egg viability [41]. For this reason, we decided to compare climatic parameters (temperature, humidity, rainfall) with the nematode egg excretion in brown bears in the same period. Environmental factors are related to the secretion of eggs in the same period of time, but mainly affect the accumulation of infectious stages in previous periods. Additionally, since eggs can remain present and viable for many years following deposition [62], seasonal or annual trends may be masked. However, our results confirmed the temporal pattern with a peak FEC in the autumn and a subsequent winter decline without proving the influence of climatic factors.

Our results did not confirm the effect of temperature, precipitation, and humidity on excretion of Baylisascaris transfuga eggs in brown bears in the mild climate of Central Europe. Prevalence, abundance, and mean egg excretion may be highly influenced by interactions such as age, sex, hyperphagia before hibernation, and previous larvated eggs ingestion, which are most probably cumulative during the prepatent period.

B. transfuga was not studied in wild brown bears in Europe as B. procyoonis in racoons in America. In general, information about the prevalence of $B$. transfuga in wild European bears is limited, and there is no data on environmental effects on the seasonal dynamics of $B$. transfuga in wild bears in Europe.

A national brown bear management plan has yet to be established, despite repeated calls by the Standing Committee of the Bern Convention and the Council of Europe. There has been little meaningful cooperation with neighbouring states sharing the same bear population (Czech Republic, Poland, Ukraine) and so consideration of management at population level, also emphasised by international experts, has been inadequate. Loss, fragmentation, and disturbance of habitat are potentially major threats to wildlife in the Carpathian Mountains. Adequate steps need to be taken to prevent permanent isolation of habitat and wildlife, including bears [63]. Research on ecology is very important to allow better understanding of the needs of bears as well as the causes of bear-human conflicts. Habitat use, social organisation, and dispersal are especially pertinent. Studies focused on the ecology and management of the brown bear in Central/Eastern Europe are needed in the future.

\section{Conclusions}

The prevalence, abundance, and mean excretion of $B$. transfuga eggs in bears were highest in autumn in all three years. We observed a relationship between the dynamics of $B$. transfuga prevalence in bears and changes in mean temperature in spring and autumn, and a seasonal trend of increasing intensity of parasitic infection from spring to autumn. The increase in the bear population, shrinking territories, and the increase in occurrence in urban areas, however, are also alarming. The dissemination of the propagative stages of bear nematodes in both urban and rural ecosystems near human dwellings could pose a risk to human health.

Author Contributions: Conceptualization, L.M. and A.K.; data curation, P.M.; formal analysis, Z.V. and M.T.; investigation, L.M., A.K., Z.V. and M.V.; methodology, L.M. and P.M.; visualization, Z.V.; writing-original draft, A.K.; writing-review \& editing, L.M., A.K. and M.V. All authors have read and agreed to the published version of the manuscript.

Funding: This study was supported by funds from the Scientific Grant Agency VEGA 2/0120/16 and VEGA 2/0099/19.

Acknowledgments: We thank Jozef Štofík and Jozef Blaško for their professional assistance.

Conflicts of Interest: The authors declare no conflict of interest. The funders had no role in the design of the study; in the collection, analyses, or interpretation of data; in the writing of the manuscript, or in the decision to publish the results. 


\section{References}

1. Aghazadeh, M.; Alson-Riggins, J.; Reljić, S.; de Ambrogi, M.; Huber, D.; Majnarić, C.; Hermosilla, C. Gastrointestinal parasites and the first report of Giardia spp. in a wild population of European brown bears (Ursus arctos) in Croatia. Vet. Arhiv. 2015, 85, 201-210.

2. Kaczensky, P.; Chapron, G.; Von Arx, M.; Huber, D.; Andrén, H.; Linnell, J.D. Status, management and distribution of large carnivores-Bear, lynx, wolf and wolverine-In Europe. Part 1. In IUCN/SSC Large Carnivore Initiative for Europe and Istituto di Ecologia Applicata; European Commission: Rome, Italy, 2013 ; p. 72.

3. Rigg, R. Status of brown bears in the Ukraine. Int. Bear News 2005, 14, 20.

4. Pravda o Medved'och: Stavy medved'ov v Chránenej Pol'ovnej Oblasti Pol'ana a Pril'ahlých Pol'ovných Revíroch [The Truth about Bears: The Number of Bears in Protected Hunting Area Pol'ana and Adjacent Hunting Areas]. Available online: https://www.pravdaomedvedoch.sk/stavy-medvedov-v-chpo-polana-aprilahlych-polovnych-reviroch/ (accessed on 9 September 2019).

5. Štofík, J.; Bural', M.; Paule, L.; Straka, M. Zhodnotenie historického rozšírenia medved'a hnedého (Ursus arctos) v Bukovských vrchoch a na pril'ahlých územiach [Evaluation of the historical distribution of the brown bear in the Bukovské vrchy and in the adjacent areas]. Natura Carpatica 2010, 51, 65-74. (In Slovak)

6. Paule, L. Rozšírenie a početnost' vel'kých šeliem na Slovensku [Distribution and population size of large carnivores in Slovakia]. In Ochrana a Manažment Vel'kých šeliem na Slovensku [Conservation and Management of Large Carnvivores in Slovakia]; Lešová, A., Antal, V., Eds.; Štátna Ochrana Prírody SR: Banská Bystrica, Slovakia, 2016; pp. 73-85. (In Slovak)

7. Králik, T. Medvede a l'udia. Ako d'alej [Bears and people. How to continue]. Chránené Územia Slovenska 2019, 93, 44-60. (In Slovak)

8. Olah, B.; Boltižiar, M.; Petrovič, F. Land use changes' relation to georelief and distance in the East Carpathians biosphere reserve. Ekológia 2006, 25, 68-81.

9. French, S.K.; Pearl, D.L.; Peregrine, A.S.; Jardine, C.M. Baylisascaris procyonis infection in raccoons: A review of demographic and environmental factors influencing parasite carriage. Vet. Parasitolol. Reg. Stud. Rep. 2019, 16, 100275. [CrossRef]

10. Samuel, W.M.; Pybus, M.J.; Kocan, A.A. Parasitic Diseases of Wild Mammals, 2nd ed.; Iowa State University Press: Iowa City, IA, USA, 2001; p. 559.

11. Kazacos, K.R. Baylisascaris procyonis and related species. In Parasitic Diseases of Wild Mammals; Samuel, W.M., Pybus, M.J., Kocan, A.A., Eds.; Iowa State University Press: Iowa City, IA, USA, 2001; pp. 301-341.

12. Bauer, C. Baylisascariosis-Infections of animals and humans with 'unusual'roundworms. Vet. Parasitol. 2013, 193, 40-412. [CrossRef]

13. Sapp, S.G.H.; Gupta, P.; Martin, M.K.; Murra, M.H.; Niedringhaus, K.D.; Pfaff, M.A.; Yabsley, M.J. Beyond the raccoon roundworm: The natural history of non-raccoon Baylisascaris species in the New World. IGP Parasites Wildl. 2017, 6, 85-99. [CrossRef]

14. Foster, G.W.; Cunningham, M.W.; Kinsella, J.M.; Forrester, D.J. Parasitic helminths of black bear cubs (Ursus americanus) from Florida. J. Parasitol. 2004, 90, 173-175. [CrossRef]

15. Partridge, J. Management Guidelines for Bears and Raccoons; The Association of British Wild Animal Keepers: Bristol, UK, 1992.

16. Moran, J.F.; Feliu, C.; Gomez, M.S. Baylisascaris transfuga (Rudolphy 1819), (Nematoda, Ascarididae); a common parasite of bears. Ecological aspects and treatment. In Proceedings of the International Conference of Aspects of Bear Conservation, Bursa, Turkey, 31 May-5 June 1994; pp. 121-124.

17. Szczepaniak, K.; Listos, P.; Lopuszynski, W.; Skrzypek, T.; Kazimierczak, W. Granulomatous peritonitis in a European brown bear caused by Baylisascaris transfuga. J. Wildl. Dis. 2012, 48, 517-519. [CrossRef]

18. Gutiérrez, Y. Diagnostic Pathology of Parasitic Infections with Clinical Correlations; Oxford University Press: Oxford, UK, 2000; p. 769.

19. Bugmyrin, S.V.; Spiridonov, S.E. First recond of natural Baylisascaris transfuga (Ascaridoidea, Nematoda) infection in wild rodents. Parasitology 2019, 146, 1714-1718. [CrossRef] [PubMed]

20. Abdelrasoul, K.; Fowler, M. Epidemiology of ascarid infection in captive carnivores. In Proceedings of the Annual Meeting of the American Association of Zoo Veterinarians, Denver, CO, USA, 7-11 October 1979; American Association of Zoo Veterinarians: Philadelphia, PA, USA, 1979; pp. 105-106. 
21. Sato, H.; Matsuo, K.; Osanai, A.; Kamiya, H.; Akao, N.; Owaki, S.; Furuoka, H. Larva migrans by Baylisascaris transfuga: Fatal neurological diseases in Mongolian jirds, but not in mice. J. Parasitol. 2004, 90, 774-781. [CrossRef] [PubMed]

22. Gavin, P.J.; Kazacos, K.R.; Shulman, S.T. Baylisascariasis. Clin. Microbiol. Rev. 2005, 18, $703-718$. [CrossRef] [PubMed]

23. Tiner, J.D. Fatalities in rodents caused by larval Ascaris in the central nervous system. J. Mammal. 1953, 34, 153-167. [CrossRef]

24. Wallach, J.D.; Boever, W.J. Diseases of Exotic Animals Medical and Surgical Management; WB Saunders CO: Philadelphia, PA, USA, 1983.

25. Crum, J.M.; Nettles, V.F.; Davidson, W.R. Studies on endoparasites of the black bear (Ursus americanus) in the southeastern United States. J. Wildl. Dis. 1978, 14, 178-186. [CrossRef] [PubMed]

26. Papini, R.; Renzoni, G.; Malloggi, M.; Casarosa, L. Visceral larva migrans in mice experimentally infected with Baylisascaris transfuga (Ascarididae: Nematoda). Parasitologia 1994, 36, 321-329.

27. King, J.M.; Black, H.C.; Hewitt, O.H. Pathology, parasitology and hematology of the black bear in New York. N. Y. Fish Game J. 1960, 7, 99-111.

28. Rogers, L.L. Parasites of black bears of the Lake Superior region. J. Wildl. Dis. 1975, 11, 189-192. [CrossRef]

29. Frechette, J.L.; Rau, M.E. Seasonal changes in the prevalance of ova of Diphyllobothrium ursi and Baylisascaris transfuga in the feces of the black bear (Ursus americanus). J. Wildl. Dis. 1978, 14, 342-344. [CrossRef]

30. Gau, R.J.; Kutz, S.; Elkin, B.T. Parasites in Grizzly Bears from the Central Canadian Arctic. J. Wildl. Dis. 1999, 35, 618-621. [CrossRef]

31. Testini, G.; Papini, R.; Lia, R.P.; Parisi, A.; Dantas-Torres, F.; Traversa, D.; Otranto, D. New insights into the morphology, molecular characterization and identification of Baylisascaris transfuga (Ascaridida, Ascarididae). Vet. Parasitol. 2011, 175, 97-102. [CrossRef] [PubMed]

32. Catalano, S.; Lejeune, M.; Tizzani, P.; Verocai, G.G.; Schwantje, H.; Nelson, C.; Duignan, P.J. Helminths of grizzly bears (Ursus arctos) and American black bears (Ursus americanus) in Alberta and British Columbia, Canada. Can. J. Zool. 2015, 93, 765-772. [CrossRef]

33. Bugmyrin, S.V.; Tirronen, K.F.; Panchenko, D.V.; Kopatz, A.; Hagen, S.B.; Eiken, H.G.; Kuznetsova, A.S. Helminths of brown bears (Ursus arctos) in the Kola Peninsula. Parasitol. Res. 2017, 116, 1755-1760. [CrossRef] [PubMed]

34. Štrkolcová, G.; Goldová, M.; Šnábel, V.; Špakulová, M.; Orosová, T.; Halán, M.; Mojžišová, J. A frequent roundworm Baylisascaris transfuga in over populated brown bears (Ursus arctos) in Slovakia: A problem worthy of attention. Acta Parasitol. 2018, 63, 167-174. [CrossRef]

35. Mituch, J. Helminth fauna of carnivores in Slovak and Czech Republics (In Slovak). Folia Venatoria 1972, 2, 161-171.

36. Goldova, M.; Ciberej, J.; Rigg, R. Medved hnedý (Ursus arctos) a parazitárne zoonózy. Brown bear (Ursus arctos) and parasitic zoonoses. Folia Venatoria 2003, 33, 123-127. (In Slovak)

37. Finnegan, S. Seasonal Dynamics in the Prevalence of Baylisascaris transfuga ova in the Faeces of the Brown Bear (Ursus arctos) in Slovakia. Master's Thesis, University of Veterinary Medicine and Pharmacy in Košice, Košice, Slovakia, 2009.

38. Major, P.; Molnár, L.; Štofík, J.; Goldová, M. Parasitofauna medved'a hnedého v NP Poloniny. Parasitofauna of the brown bear (Ursus arctos) in Poloniny National Park. In Proceedings of the Škola-Veda-prax I (School-Science-Practice), Košice, Slovakia, 24 September 2009; pp. 318-322. (In Slovak).

39. De Ambrogi, M.; Aghazadeh, M.; Hermosilla, C.; Huber, D.; Majnaric, D.; Reljic, S.; Riggins, J.E. Occurrence of Baylisascaris transfuga in wild populations of European brown bears (Ursus arctos) asidentified by a new PCR method. Vet. Parasitol. 2011, 179, 272-276. [CrossRef]

40. Orosová, T.; Goldová, M.; Ciberej, J.; Štrkolcová, G. Parasitofauna of brown bear (Ursus arctos) in the protected landscape area CHKO-Pol'ana. Folia Veterinaria 2016, 60, 20-24. [CrossRef]

41. Kresta, A.E.; Henke, S.E.; Pence, D.B. Baylisascaris procyonis in raccoons in Texas and its relationship to habitat characteristics. J. Wildl. Dis. 2010, 46, 843-853. [CrossRef]

42. Persson, I.L.; Wikan, S.; Swenson, J.E.; Mysterud, I. The diet of the brown bear Ursus arctos in the Pasvik Valley, northeastern Norway. Wildl. Biol. 2001, 7, 27-37. [CrossRef] 
43. Coles, G.C.; Bauer, C.; Borgsteede, F.H.M.; Geerts, S.; Klei, T.R.; Taylor, M.A.; Waller, P.J. World Association for the Advancement of Veterinary Parasitology (W.A.A.V.P.) methods for the detection of anthelmintic resistance in nematodes of veterinary importance. Vet. Parasitol. 1992, 44, 35-44. [CrossRef]

44. Sprent, J.F.A. Notes on Ascaris and Toxascaris, with a definition of Baylisascaris gen. nov. Parasitology 1968, 58, 185-198. [CrossRef] [PubMed]

45. Kazakos, R.; Turek, J.J. Scanning electron microscopy of the eggs of Baylisascaris procyonis, B. transfuga and Parascaris equorum and their comparison with Toxocara canis and Ascaris suum. Proc. Helm. Soc. Wash. 1983, 50, 36-42.

46. Margolis, L.; Esch, G.W.; Holmes, J.C.; Kuris, A.M.; Schad, G.A. The use of eco-logical terms in parasitology (report of an ad hoc committee of the American Society of Parasitologists). J. Parasitol. 1982, 68, 131-133. [CrossRef]

47. Rausch, R.L. Notes on the black bear, Ursus americanus, Pallas, in Alaska, with particular reference to dentition and growth. Z. Saugetierkd. 1961, 26, 65-128.

48. Clark, J.D.; Loew, F.M.; Burns, K.F. The use of dichlorvos as anthelmintic in naturally parasitised bears. JAVMA 1969, 155, 1093-1097.

49. Choquette, L.P.E.; Gibson, G.G.; Pearson, A.M. Helminths of the grizzly bear, Ursus actors, in northern Canada. Can. J. Zool. 1969, 47, 167-170. [CrossRef]

50. Manville, M. Ecto- and endoparasites of the black bear in northern Wisconsin. J. Wildl. Dis. 1978, 14, 97-100. [CrossRef] [PubMed]

51. Reed, C.; Henke, S.E.; Kresta, A.E. Frequency of deposition and location of Baylisascaris procyonis eggs in raccoon feces. J. Wildl. Dis. 2012, 48, 190-194. [CrossRef] [PubMed]

52. Page, L.K.; Gehrt, S.D.; Titcombe, K.K.; Robinson, N.P. Measuring prevalence of raccoon roundworm (Baylisascaris procyonis): A comparison of common techniques. Wildl. Soc. Bull. 2005, 33, 1406-1412. [CrossRef]

53. Snyder, D.E.; Fitzgerald, P.R. Contaminative potential, egg prevalence, and intensity of Baylisascaris procyonis-infected raccoons (Procyon lotor) from Illinois, with a comparison to worm intensity. Proc. Helminthol. Soc. Wash. 1987, 54, 141-145.

54. Kazacos, K.R. Baylisascaris Larva Migrans, Circular; U.S. Geological Survey: Reston, VA, USA, 2016 ; p. 1412.

55. Hissa, R. Physiology of the European brown bear (Ursus arctos arctos). Ann. Zool. Fennici 1997, 34, $267-287$.

56. Rigg, R. Ten years' experience of conservation and research work on large carnivores. Large carnivores: Management, research and public relation strategies of the protected areas. In Proceedings of the Alpine-Carpathian International Colloquium, Liptovský Ján, Slovakia, 2-4 July 2009.

57. Pelikán, V. Zaujímavosti z CHKO Muránska planina. Interesting observations from Muránska planina. Spravodajca Chránených Uzemí Slovenska 1983, 2, 94. (In Slovak)

58. Hell, P.; Slamečka, J. Medved' v Slovenských Karpatoch a vo Svete [The Bear in the Slovak Carpathians and in the World]; PaR Press: Bratislava, Slovakia, 1999; p. 150. (In Slovak)

59. Baláž, E. Ekológia medved’a hnedého (Ursus arctos) v Západných Tatrách a na Pol'ane [The Ecology of the Brown Bear (Ursus arctos) in the Western Tatras and in Pol'ana]. Master's Thesis, Technical University in Zvolen, Zvolen, Slovakia, 2002. (In Slovak).

60. Blizzard, E.L.; Davis, C.D.; Henke, S.; Long, D.B.; Hall, C.A.; Yabsley, M.J. Distribution, prevalence, and genetic characterization of Baylisascaris procyonis in selected areas of Georgia. J. Parasitol. 2010, 96, 1128-1133. [CrossRef]

61. Page, L.K.; Gehrt, S.D.; Cascione, A.; Kellner, K.F. The relationship between Baylisascaris procyonis prevalence and raccoon population structure. J. Parasitol. 2009, 95, 1314-1320. [CrossRef]

62. Kazacos, K.R.; Boyce, W.M. Baylisascaris larva migrans. J. Am. Vet. Med. Assoc. 1989, 195, 894-903.

63. Rigg, R.; Adamec, M. Status, ecology and management of the brown bear (Ursus arctos) in Slovakia. Slovak Wildl. Soc. 2007, 6, 128.

Publisher's Note: MDPI stays neutral with regard to jurisdictional claims in published maps and institutional affiliations. 